\title{
Increasing Australian-Indonesian monsoon rainfall linked to early Holocene sea-level rise
}

\author{
M. L. Griffiths ${ }^{1 \star}$, R. N. Drysdale ${ }^{1}$, M. K. Gagan ${ }^{2 \star}$, J.-x. Zhao ${ }^{3}$, L. K. Ayliffe ${ }^{2}$, J. C. Hellstrom ${ }^{4}$, \\ W. S. Hantoro ${ }^{5}$, S. Frisia ${ }^{1}$, Y.-x. Feng ${ }^{3}$, I. Cartwright ${ }^{6}$, E. St. Pierre ${ }^{3}$, M. J. Fischer ${ }^{7}$ and B. W. Suwargadi ${ }^{5}$
}

\begin{abstract}
The Australian-Indonesian summer monsoon affects rainfall variability and hence terrestrial productivity in the densely populated tropical Indo-Pacific region. It has been proposed that the main control of summer monsoon precipitation on millennial timescales is local insolation ${ }^{1-3}$, but unravelling the mechanisms that have influenced monsoon variability and teleconnections has proven difficult, owing to the lack of high-resolution records of past monsoon behaviour. Here we present a precisely dated reconstruction of monsoon rainfall over the past 12,000 years, based on oxygen isotope measurements from two stalagmites collected in southeast Indonesia. We show that the summer monsoon precipitation increased during the Younger Dryas cooling event, when Atlantic meridional overturning circulation was relatively weak $^{4}$. Monsoon precipitation intensified even more rapidly from 11,000 to 7,000 years ago, when the Indonesian continental shelf was flooded by global sea-level rise ${ }^{5-7}$. We suggest that the intensification during the Younger Dryas cooling was caused by enhanced winter monsoon outflow from Asia and a related southward migration of the intertropical convergence zone ${ }^{8}$. However, the early Holocene intensification of monsoon precipitation was driven by sealevel rise, which increased the supply of moisture to the Indonesian archipelago.
\end{abstract}

Improved knowledge of Australian-Indonesian summer monsoon (AISM) dynamics, particularly the factors that cause secular variability in monsoon strength, is critical to the sustainability of agricultural practices and life in the densely populated regions of the tropical Indo-Pacific. Palaeoclimate model experiments ${ }^{1}$, palaeoproductivity data ${ }^{2}$ and pollen records ${ }^{3}$ suggest that variations in Southern Hemisphere summer insolation influence AISM rainfall at orbital timescales. In contrast, other studies suggest that the dominant AISM forcing is the strength of the East Asian winter monsoon ${ }^{9}$, which is governed by the strength of air outflowing from the semi-permanent high-pressure system over Siberia (the Siberian High). During the Holocene epoch, the mechanisms that drive shorter-term millennial- to centennialscale AISM variations are poorly known, largely because existing coral records ${ }^{10,11}$ and deep-sea sediments ${ }^{12,13}$ provide only fragmentary or low-resolution information. Changes in the tropical Pacific zonal sea surface temperature (SST) gradient ${ }^{12}$ are thought to be important over this timescale for regions north of the Equator ${ }^{14-16}$, as are teleconnections with the high northern latitudes, but no detailed study has evaluated these influences south of the Equator.

Tropical speleothems have proven fruitful in recording Holocene variations in the intensity of the Asian monsoon ${ }^{14,16,17}$ where information about rainfall amount and air-mass transport is captured by the oxygen isotope ratios $\left(\delta^{18} \mathrm{O}\right)$ of speleothem calcite $^{18}$. For this study, we investigated the Holocene history of the AISM through analysis of $\delta^{18} \mathrm{O}$ in two stalagmites (LR06-B1, LR06-B3) collected from Liang Luar cave in western Flores, Indonesia $\left(8^{\circ} 32^{\prime} \mathrm{S}, 120^{\circ} 26^{\prime} \mathrm{E} ; 550 \mathrm{~m}\right.$ above sea level; Fig. 1$)$. Liang Luar is ideally located to investigate past variations in the AISM because of its strong seasonal cycle of winds and precipitation. Mean annual rainfall at the cave site is $1,200 \mathrm{~mm}$, with $\sim 69 \%$ falling during the summer monsoon season (December-March) and only $\sim 5 \%$ falling during the winter dry season (June-September) (see Supplementary Fig. S1). The rainfall maximum on Flores is linked to the lower tropospheric flow of moisture from the northwest during the southward progression of the intertropical convergence zone (ITCZ) in the austral summer. The mean winds on Flores then shift from northwesterly to southeasterly trade winds in the austral-winter dry season.

The strong seasonality of precipitation amount at Liang Luar is recorded by variations in the $\delta^{18} \mathrm{O}$ of local rainwater (Fig. 1, Supplementary Table S1). Comparisons of modern rainfall $\delta^{18} \mathrm{O}$ values using back-trajectory analysis of moisture-source regions reveal that monsoon-season rainwater is depleted in ${ }^{18} \mathrm{O}(-10.3 \%$ for amount-weighted average $\left.\delta^{18} \mathrm{O}\right)$ relative to dry-season rainwater $\left(-3.5 \%\right.$ for amount-weighted average $\left.\delta^{18} \mathrm{O}\right)$, with both seasonal sources plotting close to the Global Meteoric Water Line. This isotopic difference is related primarily to the stronger convergence and uplift of water vapour over the southern Indonesian maritime continent during austral summer.

The chronology for the Liang Luar stalagmite LR06-B1 (see Supplementary Fig. S2) $\delta^{18} \mathrm{O}$ record is constrained by 33 highprecision $\mathrm{Th} / \mathrm{U}$ dates determined by thermal ionization mass spectrometry and multi-collector inductively coupled plasma mass spectrometry (see Supplementary Figs S4 and S5, Tables S2 and S3). LR06-B1 grew in two phases: $12.6 \pm 0.12$ to $8.5 \pm 0.09$ thousand years before the present ( $k y r$ вP; the data are calibrated to the ${ }^{14} \mathrm{C}$ age scale where 'present' is defined as AD 1950) and $6.5 \pm 0.05 \mathrm{kyr}$ в to the time of collection in June 2006. The $\delta^{18} \mathrm{O}$ profile of LR06-B1 was obtained from calcite powders drilled along the central growth axis at consecutive $1-\mathrm{mm}$ increments, equating to a mean temporal

\footnotetext{
${ }^{1}$ Environmental and Climate Change Group, The University of Newcastle, Callaghan, New South Wales 2308 , Australia, ${ }^{2}$ Research School of Earth Sciences, The Australian National University, Canberra, Australian Capital Territory 0200, Australia, ${ }^{3}$ Centre for Microscopy and Microanalysis, The University of Queensland, Brisbane, Queensland 4072, Australia, ${ }^{4}$ School of Earth Sciences, The University of Melbourne, Parkville, Victoria 2010, Australia, ${ }^{5}$ Research and Development Center for Geotechnology, Indonesian Institute of Sciences, Bandung, 40135, Indonesia, 6 School of Geosciences, Monash University, Clayton, Victoria 3800, Australia, 7 Australian Nuclear Science and Technology Organisation, PMB1, Menai, New South Wales 2234, Australia. ^e-mail: Michael.Griffiths@newcastle.edu.au; Michael.Gagan@anu.edu.au.
} 


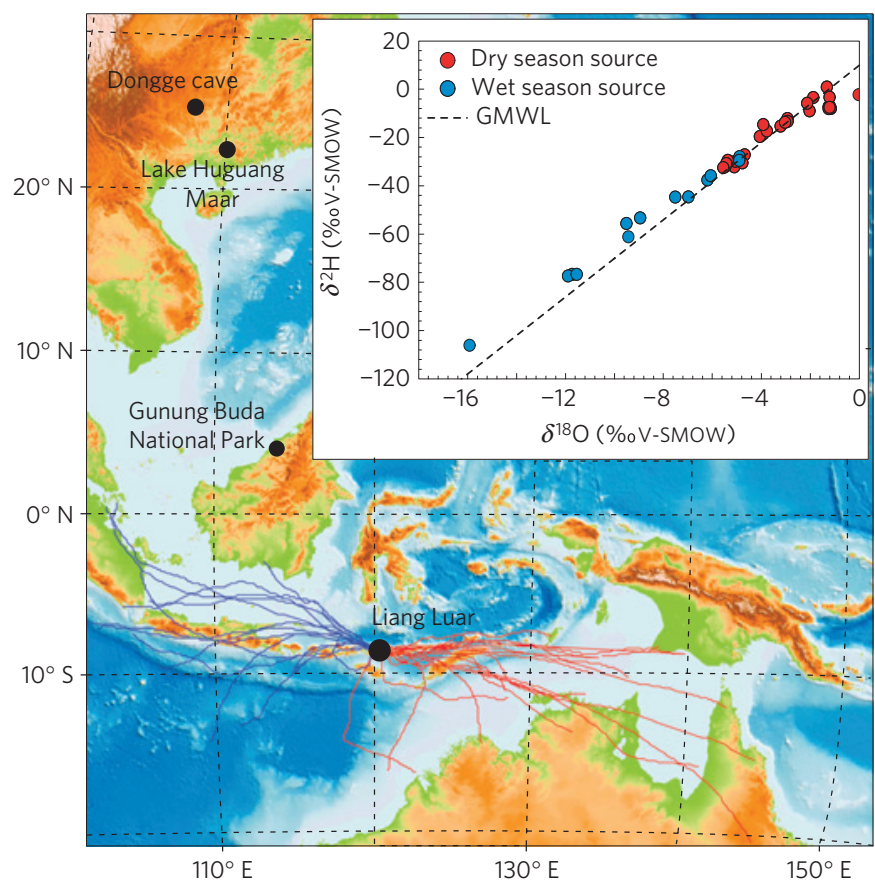

Figure 1 | Moisture-source trajectories and rainwater isotope ratios for Liang Luar cave. Physiographic map showing the location of Liang Luar and other study sites. The solid lines represent HYSPLIT (ref. 30)-calculated 96-h back-trajectories of dry-season (red) and wet-season (blue) air parcels that generated rainfall during September 2006-April 2007. The inset shows $\delta^{18} \mathrm{O}$ versus $\delta^{2} \mathrm{H}$ for the same rain days during September 2006-April 2007. Dry-season (red circles) and wet-season (blue circles) rainwater have amount-weighted average $\delta^{18} \mathrm{O}$ values of $-3.5 \%$ ( $\mathrm{V}-\mathrm{SMOW}$ ) and $-10.3 \%$, respectively. The dashed line represents the Global Meteoric Water Line (GMWL).

resolution of eight years. 'Hendy tests' 19 conducted along single growth layers reveal that changes in $\delta^{18} \mathrm{O}$ and covariation between $\delta^{18} \mathrm{O}$ and $\delta^{13} \mathrm{C}$ are negligible (see Supplementary Figs S7-S10). To cross-check the LR06-B1 record, we produced a coarser $\sim 70$-year resolution $\delta^{18} \mathrm{O}$ profile for stalagmite LR06-B3 (see Supplementary Fig. S3), collected $10 \mathrm{~m}$ from LR06-B1. The age model for this specimen, based on $29 \mathrm{Th} / \mathrm{U}$ dates, shows that it grew continuously from $10.7 \pm 0.12 \mathrm{kyr}$ вр to June 2006 (see Supplementary Figs S4 and S5). The strong similarity of the two isotopic profiles for periods of overlap (Fig. 2c,e and Supplementary Fig. S6) indicate that it is most likely that the two stalagmites deposited calcite under equilibrium conditions.

The $\delta^{18} \mathrm{O}$ values in the LR06-B1 record range from $-4.05 \%$ to $-6.92 \%$ (Fig. 2c), and reflect the combined effects of changes in global ice volume, air temperature, rainfall amount and moisture source area on stalagmite $\delta^{18} \mathrm{O}$ over the past $12.6 \mathrm{kyr}$ вр. Lower $\delta^{18} \mathrm{O}$ values are observed in the recent part of the record, with the mean value for the late Holocene ( $3-0$ kyr вр) 1.65\% lower relative to the 12.6-10.0 kyr вр period. Part of this shift reflects a $\sim 1^{\circ} \mathrm{C}$ post-glacial warming of the tropical western Pacific ${ }^{12,13}$ (accounting for $\sim 0.23 \%$ in $\delta^{18} \mathrm{O}$ ) and a $\sim 0.5 \%$ decrease in the $\delta^{18} \mathrm{O}$ of sea water due to the global ice-volume effect ${ }^{20}$. However, the combined effects of temperature and ice volume account for only $\sim 0.7 \%$ of the $1.65 \%$ Holocene shift, suggesting that the trend in stalagmite $\delta^{18} \mathrm{O}$ values cannot be explained by these factors alone.

To remove these effects from the records, we adjusted the LR06-B1 and LR06-B3 $\delta^{18} \mathrm{O}$ series for changes in Indo-Pacific warm pool SST (ref. 12) (closely coupled to tropical air temperature) and global ice volume ${ }^{5}$ (Fig. 2e) during the late glacial/Holocene. After adjustment, a $\sim 1 \%$ decrease in the $\delta^{18} \mathrm{O}$ is observed through

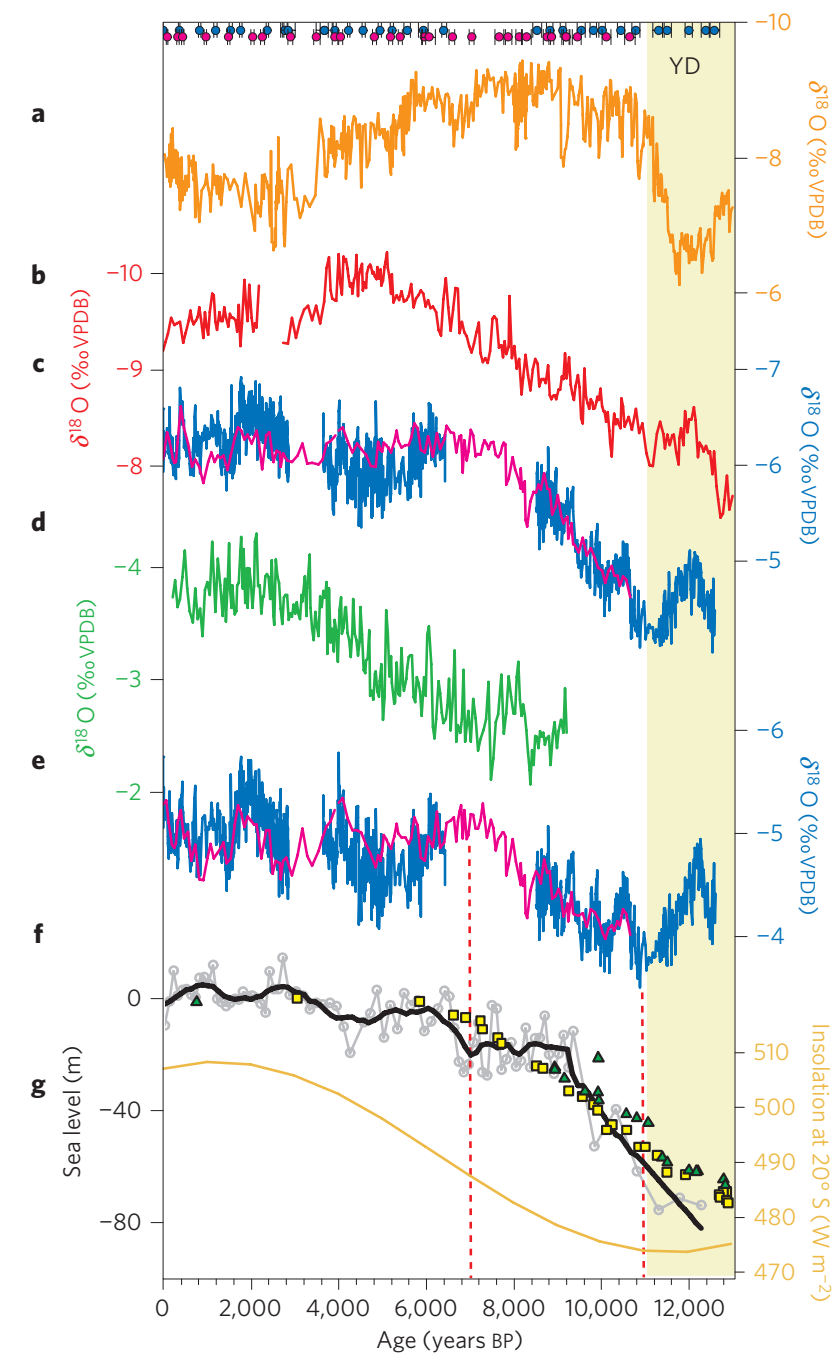

Figure 2 | Liang Luar stalagmite $\delta^{\mathbf{1 8}} \mathrm{O}$ record and other palaeoclimate records. a-d, Comparison of the Liang Luar $\delta^{18} \mathrm{O}$ record (LR06-B1, blue; LR06-B3, pink) (c) with stalagmite $\delta^{18} \mathrm{O}$ records for Dongge cave, China ${ }^{14,17}$ (orange) (a), Gunung Buda, Borneo ${ }^{16}$ (red) (b) and Botuverá cave, Brazil ${ }^{21}$ (green) (d). Th/U ages for the Liang Luar records are shown (with $2 \sigma$ errors) at the top of the figure. e, Liang Luar $\delta^{18} \mathrm{O}$ record adjusted for changes in Indo-Pacific warm pool SST (ref. 12) and global ice volume ${ }^{5}$. f. Sea-level reconstructions from the $\delta^{18} \mathrm{O}$ of Red Sea benthic foraminifera ${ }^{5}$ (grey circles) with five-point running mean (black line), and Barbados ${ }^{7}$ (green triangles) and Tahiti $^{6}$ (yellow squares) coral reef studies. The dashed red lines highlight the concurrent increases in sea level and AISM precipitation at Liang Luar. $\mathbf{g}$, December (austral summer) insolation at $20^{\circ} \mathrm{S}$. The light yellow shading indicates the timing of the Younger Dryas (YD) cooling in Greenland ${ }^{24}$.

the early to middle Holocene, which may be indicative of changes in the $\delta^{18} \mathrm{O}$ of monsoonal rainfall. Several factors may have contributed to this decrease, including: (1) variations in rainfall amount related to the intensity and/or positioning of the ITCZ; (2) changes in the seasonal balance of summer versus winter rainfall; and (3) changes in the frequency and/or intensity of El Niño/Southern Oscillation events.

The prominent feature of the adjusted Holocene $\delta^{18} \mathrm{O}$ curve is the sharp decrease in values from 11 to $7 \mathrm{kyr}$ вр (Fig. 2e). This inferred early Holocene trend towards wetter conditions culminates at the end of the deglaciation when eustatic sea-level rise had levelled off (Fig. 2f). Indeed, although higher $\delta^{18} \mathrm{O}$ values coincide with lower insolation during the early Holocene, the fastest decrease 


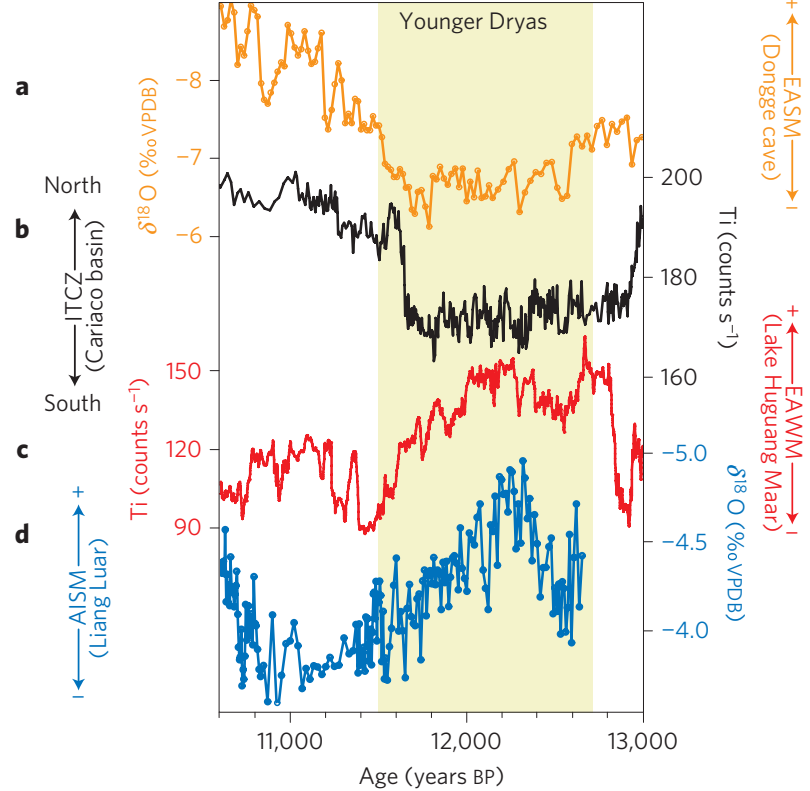

Figure 3 | Comparison of palaeoclimate records between Flores, southern China and northern South America during the Younger Dryas cooling.

a-d, A weakened East Asian summer monsoon (EASM) recorded by the Dongge cave, China, speleothem record ${ }^{17}$ (a) corresponds with a southward-displaced ITCZ over the Cariaco basin ${ }^{15}(\mathbf{b})$, stronger outflow from the East Asian winter monsoon ${ }^{8}$ (EAWM) (c) and higher monsoon rainfall over Flores (d), as indicated by lower ice-volume ${ }^{5}$ and SST (ref. 12)-adjusted $\delta^{18} \mathrm{O}$ values. The light yellow shading indicates a strong north-south inverse relationship during the time of the Younger Dryas cooling in Greenland ${ }^{24}$

in $\delta^{18} \mathrm{O}$ occurred between 11 and $9 \mathrm{kyr} \mathrm{BP}$, preceding the sharpest rise in insolation (Fig. 2g). Moreover, the Southern Hemisphere summer insolation trend through the middle to late Holocene is not evident in the Liang Luar $\delta^{18} \mathrm{O}$ record. Therefore, in contrast to other monsoon-dominated regions, such as northern Borneo ${ }^{16}$ (Fig. 2b), southern Brazil ${ }^{21}$ (Fig. 2d) and southern China ${ }^{14,17}$ (Fig. 2a), we find little evidence for insolation being responsible for the Holocene change in AISM rainfall and instead suggest that sea-level rise is a more important regional forcing mechanism. Two complementary possibilities may explain this sea-level influence. (1) Assuming monsoon moisture trajectories were broadly similar to the present, a large proportion of the summer monsoon trajectory path would have been occupied by either land surface or extremely shallow seas during the early Holocene. Thus, a lower surface area of ocean water along the dominant air-mass trajectory would have limited the availability of source moisture fuelling the monsoon. (2) Sea-level rise plus Northern Hemisphere insolation-induced heating of the South China Sea ${ }^{22}$ may have resulted in the migration of warmer waters into the Sunda area, thus resulting in higher evaporation over the source region.

The close coupling of rainfall variability in the northern and southern low latitudes with temperature fluctuations in the North Atlantic during the last glacial cycle has long been documented ${ }^{14,15,21,23}$. However, the degree to which these meridional connections extend into the southern sector of the Indo-Pacific during the late glacial/Holocene interval has not been previously observed. Superimposed on the LR06-B1 $\delta^{18} \mathrm{O}$ trend are a number of significant isotopic excursions of centennialand millennial-scale duration. Most notable is the prominent $\delta^{18} \mathrm{O}$ depletion event between $\sim 12.6$ and $\sim 11.5 \mathrm{kyr}$ вp (Fig. $3 \mathrm{~d}$ ) that occurred concurrently with the Younger Dryas cooling in the North Atlantic ${ }^{24}$.
The more depleted $\delta^{18} \mathrm{O}$ values of LR06-B1 during the Younger Dryas cooling reflect a stronger monsoon on Flores (Fig. 3d). This pattern of southern Indonesian rainfall correlates with high $\delta^{18} \mathrm{O}$ values at Dongge cave ${ }^{17}$, inferred to reflect a weakened East Asian summer monsoon (Fig. 3a). Moreover, the higher rainfall event on Flores correlates with lower titanium counts from the Cariaco basin $^{15}$, which are interpreted as lower rainfall intervals (Fig. 3b), and travertine growth phases in northeast Brazil ${ }^{25}$, indicative of higher rainfall. Thus, a stronger AISM during the Younger Dryas cooling is in parallel with higher rainfall over the southern tropics $^{25,26}$ and lower rainfall over the northern tropics ${ }^{15,17}$.

A likely explanation for these observed phase relationships, in particular between the Australian-Indonesian and East Asian summer monsoons, is an abrupt southward shift in the mean summer location of the ITCZ. The Younger Dryas cooling is thought to be the result of a marked reduction in meridional overturning circulation ${ }^{4}$ due to a major release of meltwater into the North Atlantic ${ }^{27}$. Modelling experiments indicate that these periods of reduced North Atlantic overturning highly favour the southward displacement of the ITCZ in the tropical Pacific ${ }^{28}$.

A more direct link between the AISM, and the North Atlantic and associated migration of the ITCZ during the Younger Dryas, may be the influence of the East Asian winter monsoon. Comparison of the titanium content of Lake Huguang Maar (Fig. 3c), regarded as a proxy for the strength of East Asian winter monsoon winds ${ }^{8}$, with the $\delta^{18} \mathrm{O}$ of LR06-B1 reveals a strong positive relationship. This correspondence supports previous suggestions that the AISM is largely controlled by a 'push-pull' relationship between the Australasian monsoon systems ${ }^{29}$ and hence corroborates crossequatorial links between the two regions.

Noteworthy is the absence of a Younger Dryas signal in the nearby monsoon speleothem records from northern Borneo ${ }^{16}$, which lies in stark contrast to the Liang Luar and Dongge cave records ${ }^{17}$. A possible explanation for this mismatch may be related to the geographical location of northern Borneo and its lack of seasonality. As Dongge cave and Liang Luar are positioned at the northern and southern limits of the summer ITCZ belt respectively, slight adjustments in meridional positioning are likely to have a greater influence on seasonal rainfall at those sites compared with northern Borneo.

Our results show that Southern Hemisphere summer insolation was not the most important driver of AISM rainfall during the late glacial/Holocene interval in southeast Indonesia. Reduced North Atlantic overturning circulation led to a progressive southward displacement of the austral-summer ITCZ and thus wetter conditions in southern Indonesia at the time of the Younger Dryas. However, the most sustained decrease in speleothem $\delta^{18} \mathrm{O}$, indicative of increasing monsoon rainfall, coincided with the sharpest eustatic sea-level rise, which increased moisture availability. More precisely dated high-resolution proxy records of AISM strength will be required to determine whether the patterns observed in southeast Indonesia are synchronous across the region, particularly over the north Australian land mass where the epicentre of the AISM system lies.

\section{Methods}

Stalagmites LR06-B1 and LR06-B3 were collected from a large chamber located $\sim 800 \mathrm{~m}$ from the single entrance of Liang Luar, a limestone cave underlying $\sim 50-100 \mathrm{~m}$ of soil and bedrock. The chamber has a high humidity $(\sim 100 \%$ in June 2006 and May 2007) and stable mean annual temperature of $26^{\circ} \mathrm{C}$, which closely resembles the temperature at the ground surface.

$\delta^{18} \mathrm{O}$ and $\delta^{2} \mathrm{H}$ values were determined for modern rainwater samples collected at the cave site between September 2006 and April 2007. The $\delta^{18} \mathrm{O}$ values were measured at Monash University through equilibration with $\mathrm{CO}_{2}$ at $32^{\circ} \mathrm{C}$ for $24-48 \mathrm{~h}$ in a Finnigan MAT Gas Bench and analysed using a continuous-flow technique on a Finnigan MAT 252 mass spectrometer. $\delta^{2} \mathrm{H}$ measurements were conducted through reaction with $\mathrm{Cr}$ at $850^{\circ} \mathrm{C}$ using an automated Finnigan MAT $\mathrm{H} /$ Device. $\delta^{18} \mathrm{O}$ and $\delta^{2} \mathrm{H}$ values were measured relative to internal standards (TAP 
$\delta^{18} \mathrm{O}=-5.7 \% 0, \delta^{2} \mathrm{H}=-33.9 \%$; LTP $\delta^{18} \mathrm{O}=-14.5 \% 0, \delta^{2} \mathrm{H}=-102.5 \%$ ) that were calibrated using the International Atomic Energy Agency Standard-Mean Ocean Water (SMOW), Greenland Ice Sheet Precipitation and Standard Light Antarctic Precipitation (SLAP) standards. All isotopic data are reported as parts per thousand (\%o) deviations relative to Vienna SMOW (V-SMOW) where $\delta^{18} \mathrm{O}$ and $\delta^{2} \mathrm{H}$ values of SLAP are $-55.5 \% 0$ and $-428 \%$, respectively. Analytical precision $(1 \sigma)$ for replicate measurements of the internal standards was $\pm 0.1 \% 0$ for $\delta^{18} \mathrm{O}$ and $\pm 1 \%$ for $\delta^{2} \mathrm{H}$.

A total of $62 \mathrm{Th} / \mathrm{U}$ ages were determined for stalagmites LR06-B1 and LR06-B3 using thermal ionization mass spectrometry on $\sim 300-500 \mathrm{mg}$ samples at the Centre for Microscopy and Microanalysis, University of Queensland and multi-collector inductively coupled plasma mass spectrometry on $\sim 12-40 \mathrm{mg}$ samples at the University of Melbourne. Details of the methods can be found in Supplementary Information and references therein. On the basis of these chronologies, LR06-B3 grew at an average rate of $0.12 \mathrm{~mm} \mathrm{yr}^{-1}$ since $12.6 \mathrm{kyr} \mathrm{BP}$, whereas LR06-B3 grew at $0.13 \mathrm{~mm} \mathrm{yr}^{-1}$ since $10.7 \mathrm{kyr}$ в

Calcite $\delta^{18} \mathrm{O}$ and $\delta^{13} \mathrm{C}$ were determined on powders drilled at $1 \mathrm{~mm}$ increments (8-yr resolution) along the longitudinal axis of LR06-B1. The analyses were carried out on a GV2003 continuous-flow isotope ratio mass spectrometer at the University of Newcastle, Australia. To cross-check the LR06-B3 record, $\delta^{18} \mathrm{O}$ and $\delta^{13} \mathrm{C}$ were determined at lower-resolution ( $\sim 10 \mathrm{~mm}$ increments spanning $\sim 70$ years) using an automated Kiel carbonate preparation device coupled to a Finnigan MAT-251 mass spectrometer at the Research School of Earth Sciences, The Australian National University. All isotopic data are reported as parts per thousand $(\% 0)$ deviations relative to the Vienna PeeDee Belemnite standard (VPDB). Details of the methods and their analytical precisions can be found in Supplementary Information.

Received 11 February 2009; accepted 10 July 2009; published online 2 August 2009

\section{References}

1. Wyrwoll, K. H. et al. Sensitivity of the Australian summer monsoon to tilt and precession forcing. Quat. Sci. Rev. 26, 3043-3057 (2007).

2. Holbourn, A. et al. Orbitally paced paleoproductivity variations in the Timor Sea and Indonesian throughflow variability during the last $460 \mathrm{kyr}$. Paleoceanography 20, PA3002 (2005).

3. Kershaw, A. P., van der Kaars, S. \& Moss, P. T. Late Quaternary Milankovitch-scale climatic change and variability and its impact on monsoonal Australasia. Mar. Geol. 201, 81-95 (2003).

4. McManus, J. F. et al. Collapse and rapid resumption of Atlantic meridional circulation linked to deglacial climate changes. Nature 428, 834-837 (2004).

5. Siddall, M. et al. Sea-level fluctuations during the last glacial cycle. Nature 423, 853-858 (2003).

6. Bard, E. et al. Deglacial sea-level record from Tahiti corals and the timing of global meltwater discharge. Nature 382, 241-244 (1996).

7. Peltier, W. R. \& Fairbanks, R. G. Global glacial ice volume and Last Glacial Maximum duration from an extended Barbados sea level record. Quat. Sci. Rev. 25, 3322-3337 (2006)

8. Yancheva, G. et al. Influence of the intertropical convergence zone on the East Asian monsoon. Nature 445, 74-77 (2007).

9. Miller, G. et al. Sensitivity of the Australian Monsoon to insolation and vegetation: Implications for human impact on continental moisture balance. Geology 33, 65-68 (2005).

10. Abram, N. J. et al. Seasonal characteristics of the Indian Ocean Dipole during the Holocene epoch. Nature 445, 299-302 (2007).

11. Tudhope, A. W. et al. Variability in the El Nino-Southern oscillation through a glacial-interglacial cycle. Science 291, 1511-1517 (2001)

12. Stott, L. et al. Decline of surface temperature and salinity in the western tropical Pacific Ocean in the Holocene epoch. Nature 431, 56-59 (2004).

13. Visser, K., Thunell, R. \& Stott, L. Magnitude and timing of temperature change in the Indo-Pacific warm pool during deglaciation. Nature 421, 152-155 (2003).

14. Wang, Y. J. et al. The Holocene Asian monsoon: Links to solar changes and North Atlantic climate. Science 308, 854-857 (2005).

15. Haug, G. H. et al. Southward migration of the intertropical convergence zone through the Holocene. Science 293, 1304-1308 (2001).
16. Partin, J. W. et al. Millennial-scale trends in west Pacific warm pool hydrology since the Last Glacial Maximum. Nature 449, 452-455 (2007).

17. Dykoski, C. A. et al. A high-resolution, absolute-dated Holocene and deglacial Asian monsoon record from Dongge Cave, China. Earth Planet. Sci. Lett. 233, 71-86 (2005).

18. Rozanski, K., Araguasaraguas, L. \& Gonfiantini, R. Relation between long-term trends of O-18 isotope composition of precipitation and climate. Science 258, 981-985 (1992).

19. Hendy, C. H. The isotopic geochemistry of speleothems: The calculations of the effects of different modes of formation on the isotopic composition of speleothems and their applicability as palaeclimate indicators. Geochim. Cosmochim. Acta 35, 801-824 (1971).

20. Schrag, D. P., Hampt, G. \& Murray, D. W. Pore fluid constraints on the temperature and oxygen isotopic composition of the glacial ocean. Science 272, 1930-1932 (1996).

21. Wang, X. F. et al. Interhemispheric anti-phasing of rainfall during the last glacial period. Quat. Sci. Rev. 25, 3391-3403 (2006).

22. Kienast, M., Steinke, S., Stattegger, K. \& Calvert, S. E. Synchronous tropical South China Sea SST change and Greenland warming during deglaciation. Science 291, 2132-2134 (2001).

23. Turney, C. S. M. et al. Millennial and orbital variations of El Nino/Southern Oscillation and high-latitude climate in the last glacial period. Nature 428, 306-310 (2004).

24. Members, E. C. One-to-one coupling of glacial climate variability in Greenland and Antarctica. Nature 444, 195-198 (2006).

25. Wang, X. F. et al. Wet periods in northeastern Brazil over the past $210 \mathrm{kyr}$ linked to distant climate anomalies. Nature 432, 740-743 (2004).

26. Cruz, F. W. et al. Insolation-driven changes in atmospheric circulation over the past 116,000 years in subtropical Brazil. Nature 434, 63-66 (2005).

27. Broecker, W. S. Does the trigger for abrupt climate change reside in the ocean or in the atmosphere? Science 300, 1519-1522 (2003).

28. Zhang, R. \& Delworth, T. L. Simulated tropical response to a substantial weakening of the Atlantic thermohaline circulation. J. Clim. 18, 1853-1860 (2005).

29. Magee, J. W., Miller, G. H., Spooner, N. A. \& Questiaux, D. Continuous 150 kyr monsoon record from Lake Eyre, Australia: Insolation-forcing implications and unexpected Holocene failure. Geology 32, 885-888 (2004).

30. Draxler, R. R. \& Rolph, G. D. HYSPLIT-HYbrid Single-Particle Lagrangian Integrated Trajectory Model <http://www.arl.noaa.gov/ready/hysplit4.html>

\section{Acknowledgements}

We thank N. Anderson, G. Smith and the Indonesian Institute of Sciences (LIPI) for logistical support and technical assistance with fieldwork, which was carried out under LIPI Research Permit number 3551/I/KS/2006. We also thank H. Scott-Gagan, J. Cowley and J. Cali for laboratory assistance and O. Ray-Lescure for help with Fig. 1. Comments by F. W. Cruz significantly improved the manuscript. This study was supported by an Australian Postgraduate Award to M.L.G. and an Australian Research Council grant (DP0663274) to M.K.G., J.-x. Z., R.N.D. and W.S.H. The authors gratefully acknowledge the NOAA Air Resources Laboratory (ARL) for providing the HYSPLIT transport and dispersion model and/or READY website (http://www.arl.noaa.gov/ready.html) used in this publication.

\section{Author contributions}

M.L.G. and L.K.A. were responsible for the geochemical analysis of the oxygen isotopes. M.K.G. was Chief Investigator and R.N.D., J.-x.Z., and W.S.H. were Partner Investigators. J.C.H., Y.-x.F., J.-x.Z and E.St.P. were responsible for the U/Th dating. I.C. was responsible for the isotopic analysis of the rainwater. M.J.F. helped with the interpretation of the oxygen isotopes. B.W.S. assisted in the collection of samples in June 2006. M.L.G., R.N.D., M.K.G. and S.F. wrote the paper.

\section{Additional information}

Supplementary information accompanies this paper on www.nature.com/naturegeoscience. Reprints and permissions information is available online at http://npg.nature.com/ reprintsandpermissions. Correspondence and requests for materials should be addressed to M.L.G. or M.K.G. 